Ecology

\title{
Consequences of habitat fragmentation on genetic structure of Chamaedorea alternans (Arecaceae) palm populations in the tropical rain forests of Los Tuxtlas, Veracruz, Mexico
}

\section{Consecuencias de la fragmentación del hábitat sobre la estructura genética de las poblaciones de la palma Chamaedorea alternans (Arecaceae) en el bosque tropical lluvioso de Los Tuxtlas, Veracruz, México}

\author{
Juan Manuel Peñaloza-Ramírez ${ }^{\mathrm{a}, \mathrm{e}, *}$, Bernardo Aguilar-Amezquita ${ }^{\mathrm{b}}$, Juan Núñez-Farfán ${ }^{\mathrm{b}}$, \\ Nidia Pérez-Nasser ${ }^{\mathrm{c}}$, Ana Luisa Albarrán-Lara ${ }^{\mathrm{a}}$, Ken Oyama $^{\mathrm{d}}$ \\ ${ }^{a}$ Laboratorio de Ecología Genética, Instituto de Investigaciones en Ecosistemas y Sustentabilidad, Universidad Nacional Autónoma de México, Antigua Carretera \\ a Pátzcuaro Núm. 8701, Col. Ex-Hacienda la Huerta, 58190 Morelia, Michoacán, Mexico \\ ${ }^{\mathrm{b}}$ Departamento de Ecología Evolutiva, Instituto de Ecología, Universidad Nacional Autónoma de México, Apartado postal 70-275, \\ 04510 Ciudad de México, Mexico \\ ${ }^{\mathrm{c}}$ Herbario Instituto de Investigaciones en Ecosistemas y Sustentabilidad, Universidad Nacional Autónoma de México, Antigua Carretera a Pátzcuaro Núm. 8701, \\ Col. Ex-Hacienda la Huerta, 58190 Morelia, Michoacán, Mexico \\ d Escuela Nacional de Estudios Superiores Unidad Morelia, Universidad Nacional Autónoma de México, Antigua Carretera a Pátzcuaro Núm. 8701, \\ Col. Ex-Hacienda la Huerta, 58190 Morelia, Michoacán, Mexico \\ ${ }^{\mathrm{e}}$ Department of Ecology and Evolutionary Biology, University of California Los Angeles, 4139 Terasaki Life Sciences Building, 610 Charles E. Young Drive East, \\ Los Angeles, CA 90095-7239, USA
}

Received 15 April 2015; accepted 15 April 2016

Available online 17 August 2016

\begin{abstract}
Chamaedorea alternans is a palm species that has suffered from selective extraction, and habitat loss. We collected 11 populations from fragmented and conserved forest. We assess genetic variation of $C$. alternans, genetic exchange, differentiation, bottlenecks, effective population size and signals of natural selection. Genetic diversity was higher in conserved than in fragmented forest but not significant. Fragmentation did not play a significant role in genetic diversity, possibly due to the populations heterogeneity. $C$. alternans has been subject to a pronounced isolation of trees as a product of logging, thus raising inbreeding. Bayesian clustering show a trend towards an increased structuring over the course of generations but also, indicates that populations have recently gone through a bottleneck. The bottleneck following deforestation was not severe enough to lower the effective size, this could lead to high standing genetic diversity, providing a buffer against genetic erosion. We observed directional and balancing selection in C. alternans. Maintenance of variability and increased differentiation signify that their populations have been subject to a differential selective pressure at the ecological and the landscape level, combined effect could lead to disturb pollination and dispersion processes, modifying in the long term the effective population size.

All Rights Reserved (C) 2016 Universidad Nacional Autónoma de México, Instituto de Biología. This is an open access item distributed under the Creative Commons CC License BY-NC-ND 4.0.
\end{abstract}

Keywords: Tropical forest; Genetic diversity; Genetic bottlenecks; Bayesian cluster analysis; Test of natural selection

\section{Resumen}

Chamaedorea alternans es una especie de palma que ha sufrido extracción selectiva y pérdida del hábitat. Se colectaron 11 poblaciones de bosques fragmentados y conservados. Se calculó la variación genética de C. alternans, intercambio genético, diferenciación, cuellos de botella, el tamaño

\footnotetext{
* Corresponding author.

E-mail address: juanmanuelpenalozaramirez@gmail.com (J.M. Peñaloza-Ramírez).

Peer Review under the responsibility of Universidad Nacional Autónoma de México.
} 
efectivo y las señales de selección natural. La diversidad genética fue mayor en el bosque conservado que en el fragmentado, pero no fue significativa posiblemente debido a la heterogeneidad de las poblaciones. La fragmentación no ha desempeñado un papel importante en la diversidad genética. C. alternans ha sido objeto de un marcado aislamiento de árboles, elevando así los coeficientes de endogamia. El agrupamiento bayesiano indica una tendencia hacia la estructuración con el curso de las generaciones, incluso, muestra evidencias de poblaciones que han sufrido cuellos de botella. Si el cuello de botella no fue tan severo para reducir el tamaño efectivo, esto pudo resultar en una alta diversidad genética, sirviendo como buffer contra la erosión genética. Observamos selección direccional y balanceadora en $C$. alternans. La disminución y el mantenimiento de la variabilidad y el aumento de la diferenciación significan que sus poblaciones han sido objeto de una presión diferencial a nivel ecológico y a nivel de paisaje; el efecto combinado podría llevar a alterar los procesos de polinización y dispersión, modificando a largo plazo el tamaño de la población.

Derechos Reservados (C) 2016 Universidad Nacional Autónoma de México, Instituto de Biología. Este es un artículo de acceso abierto distribuido bajo los términos de la Licencia Creative Commons CC BY-NC-ND 4.0.

Palabras clave: Bosque tropical; Diversidad genética; Cuellos de botella; Análisis de agrupamiento bayesiano; Prueba de selección natural

\section{Introduction}

Fragmentation is a process that reduces the surface of continuous forests forming several sized patches leading to modifications in the environment (Broadhurst \& Young, 2007; Young \& Pickup, 2010). At the landscape level, isolation between fragments could disturb pollination and dispersion and reduce the distribution areas, thus modifying the effective population size (Moreira, Fernandes, \& Collevatti, 2009; Young \& Clarke, 2000). Habitat degradation could upset the population's ability to respond to environmental and selective pressures (Lowe, Boshier, Bacles, \& Navarro, 2005; Willi, Van Buskirk, \& Hoffmann, 2006), but it could also in the short and long terms reduce the genetic variability of populations and affect their establishment (Farwig, Braun, \& Bohning-Gaese, 2008; Hamrick, 2010; Kettle, Hollingsworth, Jafre, Moran, \& Ennos, 2007; Zhang, Miao-Miao, Dong-Wei, \& Xiao-Yong, 2012). Habitat modification in tropical and subtropical forests has been one of the main causes for the vulnerability of tropical ecosystems (Trejo \& Dirzo, 2000). In Mexico an important reservoir of tropical forest is located in the eastern portion in the Los Tuxtlas region, Veracruz. The landscape in Los Tuxtlas is composed of a mosaic of forest fragments of tropical rain forest, secondary vegetation locally denominated as "acahuales" and large areas of grasslands (Barrera-Bassols, 1992). The main causes of deforestation are related to agriculture, cattle rising, human activities and the extraction of precious wood species (Barrera-Bassols, 1992; Guevara, Loborde, \& Sánchez-Ríos, 2005). To try to ameliorate the fragmentation impacts, the area was considered as the Biophere Reserve Los Tuxtlas in 1998 (Semarnat-RBLT, 2001) and was designed as follows: the first core area was the San Martín Tuxtla Volcano $(9,805$ ha), the second core area was the Santa Marta Sierra (18,031 ha), and the third core area was the San Martín Pajapan Volcano (1,883.3 ha). A buffer zone of 125,401 ha was also instituted bringing the total area in the biosphere reserve of Los Tuxtlas to $155,122 \mathrm{ha}$. The 3 large islands of conserved forest remained in the area, which are connected to each other by 2 large forest corridors: Catemaco and Sontecomapan serves as vegetation corridors very important to the connectivity of species (Dirzo,
González-Soriano, \& Vogt, 1997). Several studies have found that connectivity between patches is very important for the maintenance of biological diversity (Oyama, 1990). Conservation of rain forests depends on the quantity and quality of biological corridors that can mitigate the effects of deforestation (Dirzo et al., 1997; Guevara et al., 2005). Palms are among the forest species that have historically been exploited, in particular, Chamaedorea alternans (Arecaceae) is frequently used in floristry or as an ornamental plant, its populations undergoing a selective extraction and very possibly, their populations have suffered the effects of habitat loss and transformation (Hodel, 1992). Previous studies have been focused around ecological dynamics of endangered Chamaedorea species (Pérez-Farrera, Vovides, Martínez-Camilo, \& Meléndez-Martínez, 2007), and the potential distribution of $C$. elegans in Veracruz with focus on its cultivation and conservation (Pérez-Portilla \& GeissertKientz, 2004). Also, studies on population genetics performed on C. alternans and Chamaedorea ernesti-augusti highlighted high levels of genetic diversity and inbreeding among populations (Cibrián-Jaramillo et al., 2009; Luna, Epperson, \& Oyama, 2007). As well, there are studies on the taxonomy and conservation status of $C$. alternans (Bacon \& Bailey, 2006). But also, the short term genetic consequences of habitat loss and fragmentation in other palm species such as Oenocarpus bataua (Browne, Ottewell, \& Karubian, 2015). But, it is still important to know the genetic dynamics between patches and more important about how fast the effects of fragmentation would be manifested, whether they be genetic, demographic or environmental.

In this study, we hypothesize that fragmented populations should have lower levels of genetic diversity and higher levels of genetic differentiation. Furthermore, in contrast with populations in conserved sites, populations in fragments were expected to have lower levels of gene flow and more evident effects of genetic drift and inbreeding. The main objectives of this work were: (i) to evaluate the levels of genetic variation and structure among populations of Chamaedorea alternans in conserved and fragmented forest of Los Tuxtlas, Veracruz, Mexico using isozyme markers; (ii) to determine the levels of genetic exchange and genetic differentiation between populations in conserved 
forest and in fragments in order to find out if fragmented populations are in some way being affected by environmental changes resulting from the process of fragmentation, and (iii) to identify the possible signal of natural selection in populations from $C$. alternans and how this can be associated with its life history and ecology.

\section{Materials and methods}

\section{Studied species}

The species of the genus Chamaedorea, commonly named "palms," are dioecious and are distributed in neotropical rainforests and in cloud forest along the Atlantic slopes from southern San Luis Potosí and Tamaulipas to the northeast of Ecuador, western Brazil and northern Bolivia (Hodel, 1992). Mexico and Central America are the main centre of diversity and speciation of the genus Chamaedorea (Bacon \& Bailey, 2006). Chamaedorea alternans H. Wendl., is a tropical unisexual (dioecious) palm tree of up to 5 metres in height with showy inflorescences of small white or yellow flowers that are produced from October to January (Oyama, 1990). Male palms produce more flowers and inflorescences than female individuals. In general, most species of Chamaedorea have aromatic flowers, although they are mainly wind-pollinated species (Barfod, Hagen, \& Borchsenius, 2011). Also, many species have brightly coloured flowers, such as yellow, red and orange, and sticky pollen, suggesting that insects participate in the pollination (Ríos, Fuchs, Hodel, \& Cascante-Marín, 2013). The seeds are dispersed mainly by gravity and it is possible that some small mice and birds disperse the fruits at short distances (Hodel, 1992). C. alternans populations have high abundances and are fairly commonly found forming dense patches under the canopy of the forest (Bacon \& Bailey, 2006).

\section{Sampling procedure}

Leaf samples of the palm Chamaedorea alternans were randomly collected in 11 localities of tropical forests in Los Tuxtlas, Veracruz, Mexico (Table 1; Fig. 1). Deforestation of tropical rain forests in Mexico has been a vast process that has changed tropical landscapes (Dirzo et al., 1997). In the Tuxtlas region, about $10-15 \%$ of the original $2,500 \mathrm{~km}^{2}$ of rain forest that once covered the entire region remains. There are 3 core areas of management in the reserve San Martín Tuxtla Volcano, Sierra Santa Marta Volcano, the San Martín Pajapan Volcano and the buffer zone (Semarnat-RBLT, 2001). We collected 11 populations with at least 30 individuals in the 3 different core areas of management: San Martín Tuxtla Volcano, Vigía (C), Estación Caminos (C), Estación Arriba (C), Laguna (F), Cerro Borrego (F), Ruíz Cortines (F), and Cola de Pescado (F). For the core area Sierra Santa Marta Volcano, López Mateos (C), Amates Cascada (F), and Amates Norte (F). Finally, in the core San Martín Pajapan Volcano the population of Pajapan (C) (Table 1). Leaf samples were stored in the laboratory at $-70{ }^{\circ} \mathrm{C}$ until genetic analyses were conducted.

\section{Isozyme electrophoresis}

Starch gel electrophoresis was conducted following standard methods (Cheliak \& Pitel, 1984; Conkle, Hodgkiss, Nunnally, \& Hunter, 1982). Sections of fresh, young leaves were crushed in $0.3 \mathrm{~mL}$ of the grinding buffer $(3: 1[\mathrm{v}: \mathrm{v}])$ mixture of buffer YO from Yeh and O'Malley (1980) and VegII from Pitel and Cheliak (1984). Leaf extracts were adsorbed in Whatman no. 17 paper wicks that were applied to a $12 \%$ starch gel. We tested different systems of electrode and gel buffers to determine the best system for each enzyme. Anodic peroxidase (APX, E.C. 1.11.1.7, expressing 2 loci) and cathodic peroxidase (CPX, E. C. 1.11.1.7, 2 loci) resolved best in system $\mathrm{R}$ of Ridgway (Sherburne \& Lewis, 1970). Glutamic-oxaloacetic transaminase (GOT, E.C. 2.6.1.1, 2 loci) and phosphoglucose isomerase (PGI, E. C. 5.3.1.9, 2 loci) were adequately resolved in system D of Stuber, Wendel, and Goodman (1988). Esterase (EST, E.C. 3.1.1, 4 loci) and ribulose biphosphate carboxylase (RUB, E.C. 4.1.1.39, 2 loci) were run in system C of Stuber et al. (1988). Starch gels (12\%) were run at $30 \mathrm{~mA}$ for $4-6 \mathrm{~h}$ on the $\mathrm{R}$ system and for $6-8 \mathrm{~h}$ on the $\mathrm{C}$ and $\mathrm{D}$ systems. The staining recipes were modified from Wendel and Weeden (1989), and Luna, Epperson, and Oyama (2005). Enzymatic systems with more than 2 locus were numbered in ascending order beginning with the locus which had more mobility. Allelic variants within loci (allozymes) were distinguished from the products of different loci (isozymes). The alleles were numbered according to their mobility relative to the alleles of standard individuals present in all gels in each system. Allelic variants were numbered sequentially from anode to cathode.

\section{Genetic diversity and structure}

We estimated the levels of inter and intrapopulation genetic diversity in 11 populations of $C$. alternans in the Los Tuxtlas forest. Using the GENETIX 4 program (Belkhir, Borsa, Chikhi, Raufaste, \& Bonhomme, 1996-2004) we calculated the values and standard error of mean number of alleles per locus $\left(N_{a}\right)$, mean effective number of alleles $\left(N_{e}\right)$, mean observed heterozygosity $\left(H_{O}\right)$, mean expected heterozygosity $\left(H_{E}\right)$ and mean of fixation index $\left(F_{I S}\right)$ between conserved and fragmented populations. Pairwise population genetic differentiation $F_{S T}$ was estimated by the infinite alleles model (IAM) performed with $10^{4}$ permutations in the ARLEQUIN 3.5.1.2 software (Excoffier \& Lischer, 2010). Estimates of genetic exchange among conserved and fragmented populations were obtained using the program MIGRATE 3.2.7 (Beerli \& Felsenstein, 2001) by the estimation of the Bayesian-scaled long term effective population size $\left(N_{e}\right)$ and the migration rate $(m)$. Analyses were performed setting the starting value of the chain to $20^{6}$ visited and 16 recorded genealogies, with a burn-in of $50^{3}$ (Beerli \& Felsenstein, 2001). In addition, Mantel test analysis was performed in TFPGA 1.3 (Miller, 1997) to find correlations between genetic and geographic distances.

To identify possible geographic and genetic discontinuities among populations of $C$. alternans, we used the Monmonier's maximum difference algorithm with the software BARRIER 
Table 1

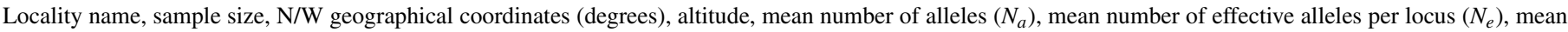

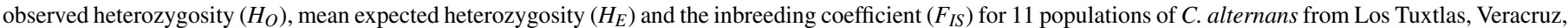
Mexico. Standard errors are included in parentheses. Bold letters mean the total for each estimation for the group.

\begin{tabular}{|c|c|c|c|c|c|c|c|c|}
\hline \multirow[t]{2}{*}{ Locality } & \multirow[t]{2}{*}{ Sample size } & \multirow[t]{2}{*}{ Coordinates } & \multirow[t]{2}{*}{ Altitude } & \multicolumn{5}{|c|}{ Genetic diversity } \\
\hline & & & & $N_{a}$ & $N_{e}$ & $H_{\mathrm{O}}$ & $H_{\mathrm{E}}$ & $F_{I S}$ \\
\hline \multicolumn{9}{|l|}{ Conserved } \\
\hline 1. Estación Caminos & 30 & $18^{\circ} 35^{\prime} / 95^{\circ} 4^{\prime}$ & 71 & $3.5(0.42)$ & $2.58(0.31)$ & $0.417(0.05)$ & $0.567(0.06)$ & $0.265(0.05)$ \\
\hline 2. Estación Arriba & 30 & $18^{\circ} 34^{\prime} / 95^{\circ} 4^{\prime}$ & 66 & $3.0(0.30)$ & $2.32(0.22)$ & $0.465(0.06)$ & $0.546(0.04)$ & $0.169(0.07)$ \\
\hline 3. Vigia & 30 & $18^{\circ} 35^{\prime} / 95^{\circ} 4^{\prime}$ & 109 & $2.6(0.44)$ & $2.0(0.33)$ & $0.388(0.06)$ & $0.462(0.07)$ & $0.159(0.06)$ \\
\hline 4. López Mateos & 30 & $18^{\circ} 26^{\prime} / 94^{\circ} 57^{\prime}$ & 214 & $3.5(0.34)$ & $2.62(0.26)$ & $0.405(0.06)$ & $0.589(0.04)$ & $0.328(0.09)$ \\
\hline 5. Pajapan & 30 & $18^{\circ} 18^{\prime} / 94^{\circ} 43^{\prime}$ & 665 & $3.3(0.37)$ & $2.55(0.28)$ & $0.351(0.06)$ & $0.564(0.05)$ & $0.395(0.08)$ \\
\hline Total & & & & 3.62 & 2.696 & 0.443 & 0.621 & 0.263 \\
\hline \multicolumn{9}{|l|}{ Fragmented } \\
\hline 6. Ruiz Cortines & 30 & $18^{\circ} 31^{\prime} / 95^{\circ} 7^{\prime}$ & 939 & $3.1(0.37)$ & $1.99(0.20)$ & $0.362(0.22)$ & $0.508(0.19)$ & $0.296(0.09)$ \\
\hline 7. Amates Cascada & 30 & $18^{\circ} 20 / 95^{\circ} 3^{\prime}$ & 881 & $3.9(0.22)$ & $2.84(0.20)$ & $0.468(0.20)$ & $0.626(0.08)$ & $0.261(0.07)$ \\
\hline 8. Amates CNorte & 30 & $18^{\circ} 30^{\prime} / 95^{\circ} 03^{\prime}$ & 228 & $3.5(0.20)$ & $2.53(0.17)$ & $0.411(0.14)$ & $0.581(0.10)$ & $0.288(0.06)$ \\
\hline 9. Laguna & 30 & $18^{\circ} 35^{\prime} / 95^{\circ} 05^{\prime}$ & 327 & $3.4(0.32)$ & $2.57(0.25)$ & $0.439(0.20)$ & $0.621(0.15)$ & $0.296(0.07)$ \\
\hline 10. Cerro Borrego & 30 & $18^{\circ} 37^{\prime} / 95^{\circ} 05^{\prime}$ & 143 & $3.3(0.30)$ & $2.29(0.19)$ & $0.465(0.17)$ & $0.589(0.14)$ & $0.211(0.04)$ \\
\hline 11. Cola de Pescado & 30 & $18^{\circ} 38 / 95^{\circ} 04^{\prime}$ & 172 & $3.1(0.32)$ & $2.42(0.27)$ & $0.414(0.20)$ & $0.583(0.18)$ & $0.298(0.05)$ \\
\hline Total & & & & 3.60 & 2.617 & 0.424 & 0.603 & 0.275 \\
\hline
\end{tabular}

version 2.2 (Manni, Guerard, \& Heyer, 2004), a program that creates a map of sampling locations from their geographical coordinates. Barriers were then represented on the map by identifying the maximum values within the population pairwise genetic distance matrix. We utilized an average square distances
(ASD) matrix of (Goldstein, Ruiz-Linares, Cavalli-Sforza, \& Feldman, 1995; Slatkin, 1995) estimated for 11 populations of $C$. alternans. Resampling random subsets of individuals within populations provided 100 bootstrap replicate distances were constructed utilizing the MSA program (Dieringer \&

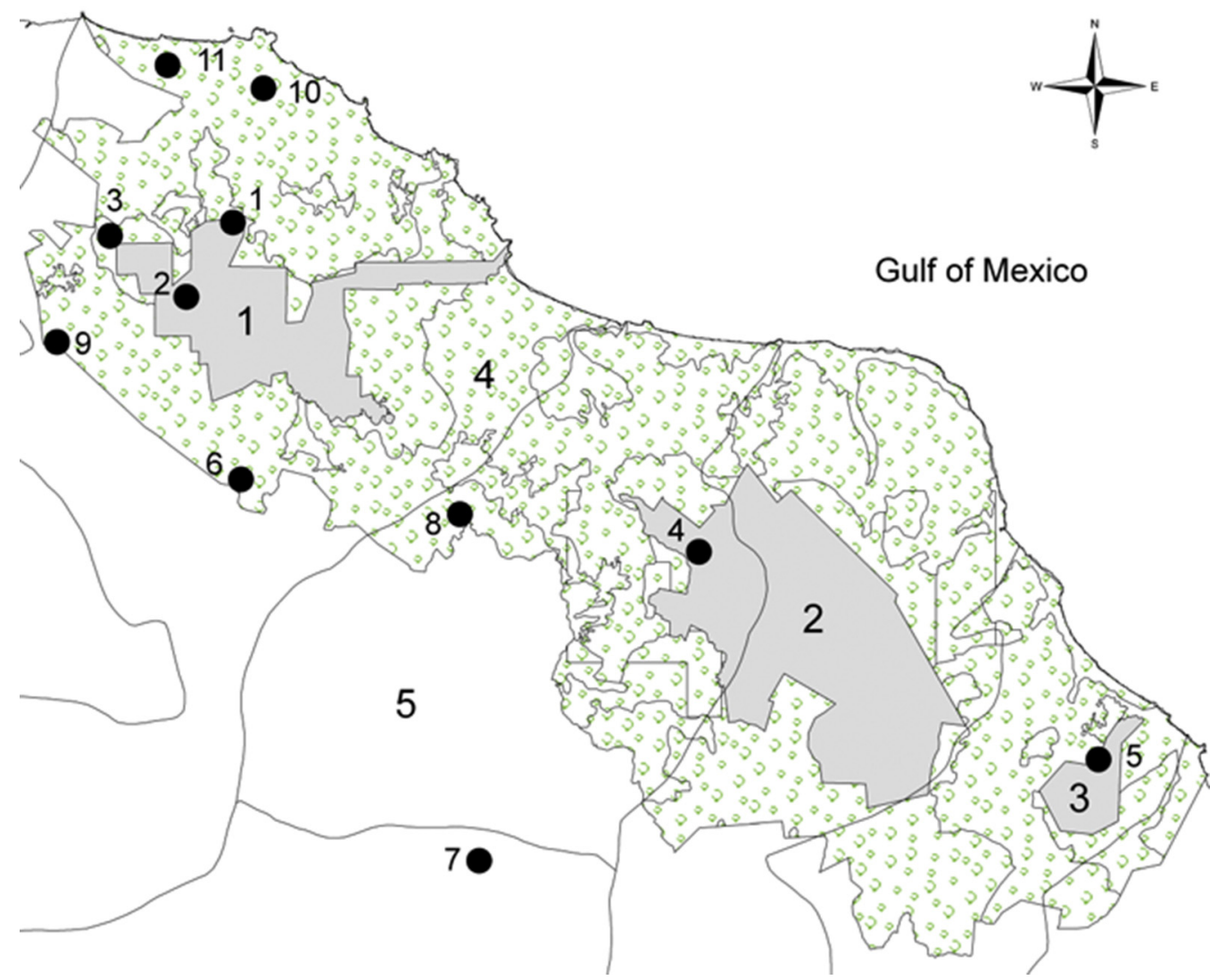

Figure 1. Map showing the delimitation of 11 populations of $C$. alternans sampled in the Biosphere Reserve Los Tuxtlas (black circles). We include the first core area the San Martín Tuxtla Volcano (1), the second core area the Santa Marta Sierra (2) and the third core area was the San Martín Pajapan Volcano (3) with grey colour. The number 4 shows the buffer zone in light green and 5 shows the Catemaco Lake. 
Schlötterer, 2003) to achieve statistical significance for the predicted barriers.

\section{Population bottleneck, size change and test of selection}

We used the software BOTTLENECK 1.2 (Piry, Luikart, \& Cornuet, 1999) to detect population bottlenecks, using the 2 genetic groups previously obtained with STRUCTURE. Recent bottlenecks, could be defined as a population where the rare alleles are the first to be lost decreasing the mean number of alleles per locus. In contrast, heterozygosity is less affected, producing a transient excess in heterozygosity relative to that expected given the resulting number of alleles (Cornuet \& Luikart, 1996; Luikart \& Cornuet, 1998). To test the data set, we used $90 \%$ stepwise and $10 \%$ multistep mutations $10^{4}$ iterations with the Wilcoxon signed-rank test, and the stepwise mutation (SMM), the infinite allele (IAM) and 2-phase mutation (TPM) models. Additionally, we also estimated the effective population size in populations of $C$. alternans with the program LDNe (Waples \& Do, 2008), which implements the bias-correction method developed by Waples (2006) to obtain $N_{e}$ from each sample of $\mathrm{S}$ individuals. For $\mathrm{LDNe}$, we used the criterion $\mathrm{P}_{\text {crit }}=0.02$ (alleles with frequency $<0.02$ are excluded), which generally provides a good balance among accuracy and bias (Waples \& Do, 2008). Confidence intervals (CIs) for $N_{e}$ were based in the chi-square approximation implemented by LDNe (Waples, 2006).

Additionally, we tested the loci for patterns indicative of selection using LOSITAN which evaluates the relationship between $F_{S T}$ and expected heterozygosity $\left(H_{E}\right)$ to identify outlier loci. Theoretically, a shared demographic history should result in similar $F_{S T} / H_{E}$ values for all loci; those that deviate may be candidates for selection (Beaumont, 2005). We ran 99,000 simulations starting with a neutral mean $F_{S T}$ using either the entire dataset and then we tested the different groups of $C$. alternans. Finally, we used the frequentist method to test selection with the program FDIST2 (Beaumont \& Balding, 2004). This approach calculates $\theta$, Weir and Cockerham (1984) as an estimator of diversity for each locus in the sample. This method provides evidence for selection by looking for outliers with higher/lower observed $F_{S T}$ values, controlling for heterozygosity (Beaumont $\&$ Balding, 2004). Coalescent simulations were then performed to determine the quantiles of the simulated $F_{S T}$ within which the observed $F_{S T}$ 's fell, and significance level ( $P$-values) for each locus. Simulation parameters were under an infinite allele mutation model for 100 demes, and sample sizes 100 .

\section{Bayesian cluster analysis}

A Bayesian cluster analysis was conducted using STRUCTURE version 2.3.3 (Falush, Stephens, \& Pritchard, 2003; Hubisz, Falush, Stephens, \& Pritchard, 2009; Pritchard, Stephens, \& Donnelly, 2000). In this analysis individuals are probabilistically assigned to one of the predefined $K$ populations (gene pools) to identify the optimal number of genetic groups (Evanno, Regnaut, \& Goudet, 2005). The optimum number of groups $(K)$ was determined by varying the value of $K$ from 1 to 10 and running the analysis 10 times per $K$ value, in order to determine the maximum value of posterior likelihood [ $\mathrm{LnP}$ (D)]. Each run was performed using $50^{4}$ burn-in periods and $10^{6}$ Markov Chain Monte Carlo (MCMC) repetitions after burn-in. We used a model allowing for admixture with correlated allelic frequencies without any prior information. Also, we determined the most probable value of $K$ using the maximum value of $\Delta K$ according to Evanno et al. (2005) implemented in the program Structure Harvester 0.6.1 (Earl \& Von Holdt, 2011).

\section{Results}

The values of the genetic diversity parameters estimated in 11 populations of $C$. alternans (Table 1) were higher in conserved $\left(N_{a}=3.62, N_{e}=2.696, H_{O}=0.443\right)$ than in fragmented populations $\left(N_{a}=3.60, N_{e}=2.617, H_{O}=0.424\right)$ (Table 1); although differences were not statistically significant in an Anova 1-way test. Wright's inbreeding coefficients within populations $\left(F_{I S}\right)$ were in all cases positive, indicating a deficit of heterozygotes (Table 1) that was slightly higher in fragmented $\left(F_{I S}=0.275\right)$ than in conserved populations $\left(F_{I S}=0.263\right)$, although not showing statistical significance in a 1-way Anova test. Pairwise genetic differentiation among populations indicated that the highest genetic differentiation based on $F_{S T}$ (Table 2) was observed between conserved and fragmented populations: Vigía/Estación Caminos $\left(F_{S T}=0.29\right)$, Ruíz Cortines/Estación Caminos $\left(F_{S T}=0.28\right)$, and Cerro Borrego/Vigía $\left(F_{S T}=0.27\right)$, while moderate differentiation was observed between López Mateos/Pajapan $\left(F_{S T}=0.134\right)$, Cerro Borrego/Estación Arriba $\left(F_{S T}=0.169\right)$. Finally, lower differentiation was found between Cola de Pescado/Laguna $\left(F_{S T}=0.066\right)$. Mantel test did not show statistical correlation between geographic and genetic distances estimated by the linearized $F_{S T}\left(F_{S T} / 1-F_{S T}\right)$. Levels of gene exchange detected with MIGRATE resulted in moderate to high values among all populations of C. alternans (Table 3). While the highest values of gene flow were detected between populations in conserved and fragmented forest $\left(N_{m} 1-2.12\right)$. Moderate levels of gene flow were observed between populations in fragmented and conserved forest $\left(N_{m}=1-1.9\right)$. The lowest number of migrants per generation was identified within conserved and fragmented populations $\left(N_{m}=0.53-0.9\right)$.

\section{Population bottleneck, size change and test of selection}

The results of the analysis to test the evidence of recent bottlenecks (excess heterozygosity) using the infinite allele model (IAM), 2-phase model (TPM) and stepwise mutation models (SMM) are presented in Table 4. Results were-significant $(p<0.50)$ for IAM $p=0.0003$ and TPM $p=0.001$ and the SMM $p=0.006$ in the lociCPX-2, APX-2 and GOT-2 models. Populations of the 2 genetic groups exhibited evidence of excess heterozygosity for $C$. alternans populations suggesting that the populations have recently undergone a bottleneck. The results of estimation of effective population size $\left(N_{e}\right)$ performed with the program $\mathrm{LDNe}$ in populations of $C$. alternans show that the both genetic groups had the moderated values in the first group ( $N_{e}=164$ individuals), followed by the second group $\left(N_{e}=154\right)$; 
Table 2

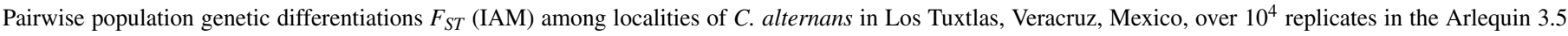
software (Excoffier \& Lischer, 2010).

\begin{tabular}{|c|c|c|c|c|c|c|c|c|c|c|c|}
\hline$F_{S T}$ & $\begin{array}{l}\text { Estación } \\
\text { Caminos }\end{array}$ & $\begin{array}{l}\text { Estación } \\
\text { Arriba }\end{array}$ & Vigia & $\begin{array}{l}\text { López } \\
\text { Mateos }\end{array}$ & Pajapan & $\begin{array}{l}\text { Ruiz } \\
\text { Cortines }\end{array}$ & $\begin{array}{l}\text { Amates } \\
\text { Casca }\end{array}$ & $\begin{array}{l}\text { Amates } \\
\text { Norte }\end{array}$ & Laguna & $\begin{array}{l}\text { Cerro } \\
\text { Borrego }\end{array}$ & $\begin{array}{l}\text { Cola de } \\
\text { Pescado }\end{array}$ \\
\hline Estación Caminos & - & & & & & & & & & & \\
\hline Estación Arriba & 0.213 & - & & & & & & & & & \\
\hline Vigía & 0.299 & 0.175 & - & & & & & & & & \\
\hline López Mateos & 0.122 & 0.235 & 0.319 & - & & & & & & & \\
\hline Pajapan & 0.222 & 0.143 & 0.228 & 0.134 & - & & & & & & \\
\hline Ruiz Cortines & 0.280 & 0.174 & 0.299 & 0.197 & 0.078 & - & & & & & \\
\hline Amates Cascada & 0.180 & 0.111 & 0.187 & 0.195 & 0.122 & 0.147 & - & & & & \\
\hline Amates CNorte & 0.219 & 0.130 & 0.253 & 0.230 & 0.146 & 0.178 & 0.070 & - & & & \\
\hline Laguna & 0.208 & 0.166 & 0.260 & 0.140 & 0.073 & 0.127 & 0.109 & 0.133 & - & & \\
\hline Cerro Borrego & 0.224 & 0.169 & 0.274 & 0.164 & 0.076 & 0.100 & 0.139 & 0.167 & 0.070 & - & \\
\hline Cola de Pescado & 0.244 & 0.144 & 0.210 & 0.161 & 0.033 & 0.072 & 0.117 & 0.155 & 0.066 & 0.073 & - \\
\hline
\end{tabular}

Table 3

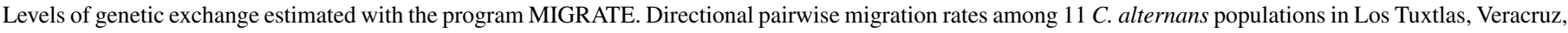

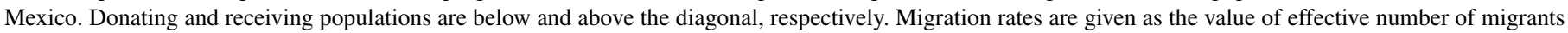
per generation $\left(N_{m}\right)$.

\begin{tabular}{|c|c|c|c|c|c|c|c|c|c|c|c|}
\hline \multirow{2}{*}{$\begin{array}{l}\text { +Receiving } \\
\text { Population }\end{array}$} & \multicolumn{11}{|c|}{ Population } \\
\hline & EstCam C & EstArrib C & Vigia C & LopezMat C & Pajapan C & RuizCort F & AmatCasc F & AmatCeno F & Laguna F & CerrBorre F & ColPesc F \\
\hline EstCam C & - & 1.77 & 0.615 & 0.759 & 1.038 & 1.023 & 0.591 & 1.046 & 1.33 & 1.047 & 0.990 \\
\hline EstArrib C & 1.00 & - & 0.951 & 0.673 & 0.790 & 0.859 & 1.379 & 0.708 & 1.015 & 0.849 & 1.965 \\
\hline Vigia C & 1.329 & 0.566 & - & 1.007 & 0.930 & 1.059 & 1.079 & 0.979 & 0.526 & 0.975 & 1.260 \\
\hline LopezMat C & 0.991 & 1.377 & 0.514 & - & 1.061 & 1.228 & 0.734 & 0.771 & 0.844 & 0.697 & 1.498 \\
\hline Pajapan C & 1.104 & 1.034 & 0.317 & 0.900 & - & 0.848 & 1.044 & 0.748 & 0.847 & 1.227 & 1.047 \\
\hline RuizCort F & 0.674 & 1.213 & 0.857 & 0.895 & 0.864 & - & 0.755 & 0.828 & 0.820 & 1.407 & 0.571 \\
\hline AmatCasc F & 1.718 & 1.514 & 1.517 & 0.564 & 0.535 & 1.517 & - & 1.603 & 1.078 & 1.015 & 1.171 \\
\hline AmatCeno F & 0.634 & 1.267 & 0.643 & 0.775 & 1.098 & 0.757 & 2.128 & - & 0.770 & 0.706 & 0.560 \\
\hline Laguna F & 1.066 & 0.574 & 1.086 & 1.607 & 0.492 & 1.273 & 1.411 & 1.213 & - & 1.270 & 0.820 \\
\hline CerrBorre F & 0.806 & 1.292 & 1.164 & 1.209 & 1.229 & 1.074 & 0.404 & 1.057 & 0.691 & - & 1.228 \\
\hline ColPesc F & 0.867 & 0.459 & 1.272 & 1.277 & 1.352 & 1.242 & 1.841 & 0.891 & 0.616 & 0.850 & - \\
\hline
\end{tabular}

Table 4

Bottleneck analysis for $C$. alternans populations in Los Tuxtlas, Veracruz, Mexico using Wilcoxon rank test under infinite allele, stepwise mutation and 2 phase model. Parameters for TPM: variance $=10 \%$, proportion of $\mathrm{SMM}=90 \%$, estimation based on $10^{4}$ replications. P, probability. IAM, infinite allele model; TPM, 2 phase model; SMM, stepwise mutation model. *** indicate significant deviation from equilibrium as value less than 0.01. Also, we include the results obtained for the estimation of the population effective size for the 2 genetic groups, values obtained with the program LDNe.

\begin{tabular}{lcr}
\hline Models & Group1 & \multicolumn{1}{c}{ Group2 } \\
\hline IAM & $0.0003^{* * *}$ & $0.003^{* * *}$ \\
TPM & $0.0001^{* * *}$ & $0.001^{* * *}$ \\
SMM & $0.001^{* * *}$ & $0.006^{* * *}$ \\
LDNe & 164.6 & 154.8 \\
\hline
\end{tabular}

in all cases, estimates had high Jacknife support and a good confidence interval (CIs) (Table 4). Results of analyses to detect outlier loci performed with the FDIST2 and with the LOSITAN programs are presented in Table 5. With both approaches, based on simulated and observed FST values, could identified 4 loci (GOT-2, EST-1, APX-1 and GOT-1) as outliers showing footprints of selection in populations from conserved and fragmented populations with a 5\% significance level. One of these outlier significant loci the GOT-1 did show higher $F_{S T}$ values that probably indicated a signal of directional selection. The other 3 outlier significant loci the GOT-2, EST-1 and APX-1 appearing in the lower tail of the $F_{S T}$ distribution that possibly suggested a signature potentially affected by balancing selection (Table 5).

\section{Cluster analysis}

The highest posterior probability was obtained from Bayesian likelihood [LnP (D)] and the $\Delta K$ Evanno et al. (2005) approach implemented in the program Structure Harvester (Earl \& Von Holdt, 2011). These statistics determined that $K=2$ is the optimum value for the number of genetic clusters included in the analysis (Fig. 2). Figure 3 shows a conserved (i.e. Cluster 1, green) and a fragmented (i.e. Cluster 2, red) group of genotypes, forest populations being consistently structured according to fragment type. Conserved populations (i.e. Cluster 1, green) Estación Caminos C, Estación Arriba C, Vigía C, and López Mateos $\mathrm{C}$ form their own genetic group (green) with an ancestry coefficient $Q$ from 0.532 to 0.882 . Populations from fragmented forest (i.e. Cluster 2, red), such as Amates Cascada F, Amates 
Table 5

LOSITAN and FDIST2 test of detection of selection in populations of $C$. alternans from conserved and fragmented landscapes. Bold numbers show the significant deviation of neutrality in a particular locus and the type of selection involved.

\begin{tabular}{|c|c|c|c|c|c|c|c|}
\hline \multirow[t]{2}{*}{ Loci } & \multicolumn{2}{|c|}{ Lositan test } & \multirow[t]{2}{*}{$P$} & \multicolumn{2}{|l|}{ FDIST2 test } & \multirow[t]{2}{*}{$P$} & \multirow[t]{2}{*}{ Selection } \\
\hline & $H_{E}$ & $F_{S T}$ & & Sample $H_{E}$ & Sample $F_{S T}$ & & \\
\hline \multicolumn{8}{|l|}{ Group 1} \\
\hline \multicolumn{8}{|l|}{ Conserved } \\
\hline APX-1 & 0.761 & 0.162 & 0.983 & 0.778 & 0.145 & 0.209 & \\
\hline APX-2 & 0.741 & 0.073 & 0.558 & 0.767 & 0.064 & 0.077 & \\
\hline CPX-1 & 0.676 & 0.125 & 0.864 & 0.722 & 0.103 & 0.077 & \\
\hline CPX-2 & 0.638 & 0.098 & 0.731 & 0.716 & 0.077 & 0.028 & \\
\hline GOT-1 & 0.707 & 0.075 & 0.569 & 0.790 & 0.505 & 0.000 & \\
\hline GOT-2 & 0.755 & 0.049 & 0.302 & 0.776 & 0.048 & 0.001 & Balancing \\
\hline PGI-1 & 0.733 & 0.033 & 0.139 & 0.776 & 0.044 & 0.081 & \\
\hline PGI-2 & 0.610 & 0.048 & 0.350 & 0.649 & 0.044 & 0.091 & \\
\hline EST-1 & 0.625 & -0.008 & 0.000 & 0.767 & 0.413 & 0.012 & Balancing \\
\hline EST-2 & 0.584 & 0.098 & 0.726 & 0.761 & 0.519 & 0.100 & \\
\hline RUB-1 & 0.675 & 0.065 & 0.726 & 0.765 & 0.076 & 0.116 & \\
\hline RUB-2 & 0.686 & 0.067 & 0.491 & 0.792 & 0.268 & 0.184 & \\
\hline MDH & 0.629 & 0.029 & 0.189 & 0.757 & 0.257 & 0.227 & \\
\hline PER & 0.606 & 0.034 & 0.209 & 0.624 & 0.281 & 0.189 & \\
\hline \multicolumn{8}{|l|}{ Group 2} \\
\hline \multicolumn{8}{|c|}{ Fragmented } \\
\hline APX-1 & 0.700 & 0.038 & 0.022 & 0.748 & 0.035 & 0.012 & Balancing \\
\hline APX-2 & 0.748 & 0.057 & 0.089 & 0.786 & 0.054 & 0.014 & \\
\hline CPX-1 & 0.708 & 0.125 & 0.590 & 0.723 & 0.122 & 0.411 & \\
\hline CPX-2 & 0.725 & 0.178 & 0.869 & 0.782 & 0.122 & 0.400 & \\
\hline GOT-1 & 0.646 & 0.163 & 0.790 & 0.548 & 0.634 & 0.000 & Positive \\
\hline GOT-2 & 0.739 & 0.089 & 0.333 & 0.757 & 0.079 & 0.200 & \\
\hline PGI-1 & 0.660 & 0.043 & 0.049 & 0.702 & 0.048 & 0.049 & \\
\hline PGI-2 & 0.614 & 0.090 & 0.343 & 0.655 & 0.800 & 0.257 & \\
\hline EST-1 & 0.577 & 0.070 & 0.232 & 0.629 & 0.097 & 0.402 & \\
\hline EST-2 & 0.626 & 0.148 & 0.703 & 0.637 & 0.140 & 0.291 & \\
\hline RUB-1 & 0.513 & 0.043 & 0.063 & 0.605 & 0.035 & 0.040 & \\
\hline RUB-2 & 0.664 & 0.100 & 0.394 & 0.728 & 0.082 & 0.246 & \\
\hline MDH & 0.672 & 0.065 & 0.174 & 0.717 & 0.067 & 0.135 & \\
\hline PER & 0.649 & 0.190 & 0.886 & 0.729 & 0.145 & 0.192 & \\
\hline
\end{tabular}

CNorte $\mathrm{F}$ and Laguna belong to the fragmented genetic group (red) with ancestry coefficient $(Q)$ going from 0.759 to 0.853 . The remaining populations of Cerro Borrego F, and Cola de Pescado $\mathrm{F}$ sites were principally grouped within the green genetic cluster $(Q 0.732-0.848)$. Figure 3 displays the distribution of ancestry proportions by means of pie charts placed on each collection site. According to the Barriers analysis, using 100 bootstrap replicates of ASD matrixes, 4 barriers were identified in the 11 populations of $C$. alternans tested with over $50 \%$ bootstrap support (Fig. 3). The most significant barrier, with a bootstrap support of $95 \%$, separates the eastern part of Catemaco Lake and south of Catemaco, Veracruz. The second barrier, with $89 \%$ bootstrap value, divides the San Martin Pajapan volcano and the rest of the populations of $C$. alternans. The third barrier with a $79 \%$ bootstrap support separated populations in the northern area of Los Tuxtlas, such as Cola de Pescado and Cerro Borrego, from populations in conserved sites from Vigia and Estación Caminos. The fourth barrier, with a $68 \%$ bootstrap support, separated the populations from Laguna and Estación Arriba from populations in the north of Catemaco Lake, such as Ruíz Cortines and Amates Norte (Fig. 3).

\section{Discussion}

We studied the joint effect of landscape changes, altering environmental conditions and genetic diversity on the palm Chamaedora alternans. We observed that estimated parameters of genetic diversity were higher in conserved $\left(N_{a}=3.62\right.$, $\left.N_{e}=2.69, H_{O}=0.44\right)$ than in fragmented forests $\left(N_{a}=3.60\right.$, $\left.N_{e}=2.61, H_{O}=0.42\right)$ even if the differences were not statistically significant (Table 1). These results, suggested that fragmentation effect did not play a significant role on genetic diversity in the isolated habitats, as previously reported in tree species (Aguilar, Quesada, Ashworth, Herrerias, \& Lobo, 2008; Figueroa-Esquivel, Puebla-Olivares, Eguiarte, \& Núñez-Farfán, 2010; Kettle et al., 2007; Zhang et al., 2012). Particularly, for C. alternans, which has been subject to increasing pressures for at least 50 years, which in combination with the high rates of deforestation in its geographic areas (Bacon \& Bailey, 2006) and forest conversion to agriculture and grasslands, has caused habitat loss, pollinators, and dispersers (Govaerts \& Dransfield, 2005; Hodel, 1992). Although, the relaxed effect on genetic diversity is probably due to the substantial amount of population 


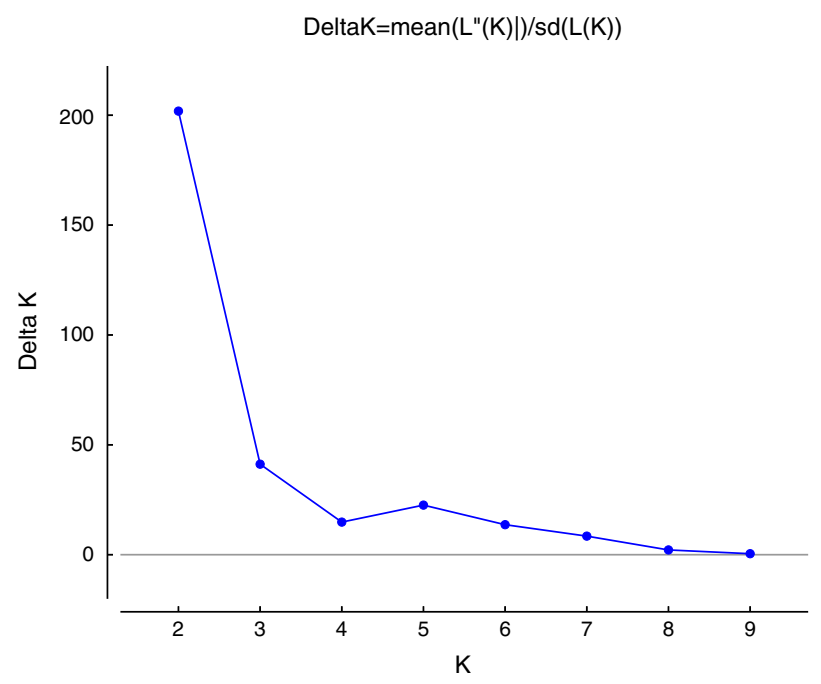

Figure 2. Values of $\Delta K$ plotted against $K$, the peak indicates the most probable number of genetic groups given the data using Structure Harvester (Earl \& Von Holdt, 2011).

heterogeneity even if they belong to the same type of fragmentation. This outline particularly indicates different evolutionary histories of populations within a single group, even if they present common geographical and ecological characteristics.
These results suggest that, in the short term, genetic diversity can be maintained in fragmented landscapes among early generations of this long-lived palm species, despite increasing levels of within- and between-population genetic structure among populations (Browne et al., 2015; Kettle et al., 2007). But also, could be evidence of the early signals for an anthropogenic impact on the evolutionary trajectory for $C$. alternans in our study area. Similarly, in $C$. alternans inbreeding coefficients underlined higher values in populations from fragments $\left(F_{I S}=0.275\right)$ and conserved forest $\left(F_{I S}=0.263\right)$ and indicate a deficiency of heterozygosity relative to expected in Hardy-Weinberg equilibrium. Populations of $C$. alternans have been subject to a gradually and pronounced isolation of mature trees in fragmented areas as the product of selective logging that reduces the density of adult trees, thus raising inbreeding coefficients. We can expect changes in reproductive traits, such as the decrease in outcrossing rate because of adult trees in disturbed landscapes generally are mating more frequently with closely related individuals, or even through autogamous pollination (e.g. Andre, Lemes, Grogan, \& Gribel, 2008; Kettle et al., 2007; Lowe et al., 2005; Oostermeijer, Luijten, \& Den Nijs, 2003). Chamaedorea and other palm genera have local aggregations of specific cohorts or sexes (Porter-Morgan, 2007; Souza \& Martins, 2003; Svenning, 2001). If there is mating-pair heterogeneity, or if floral resources from either females or males are not available

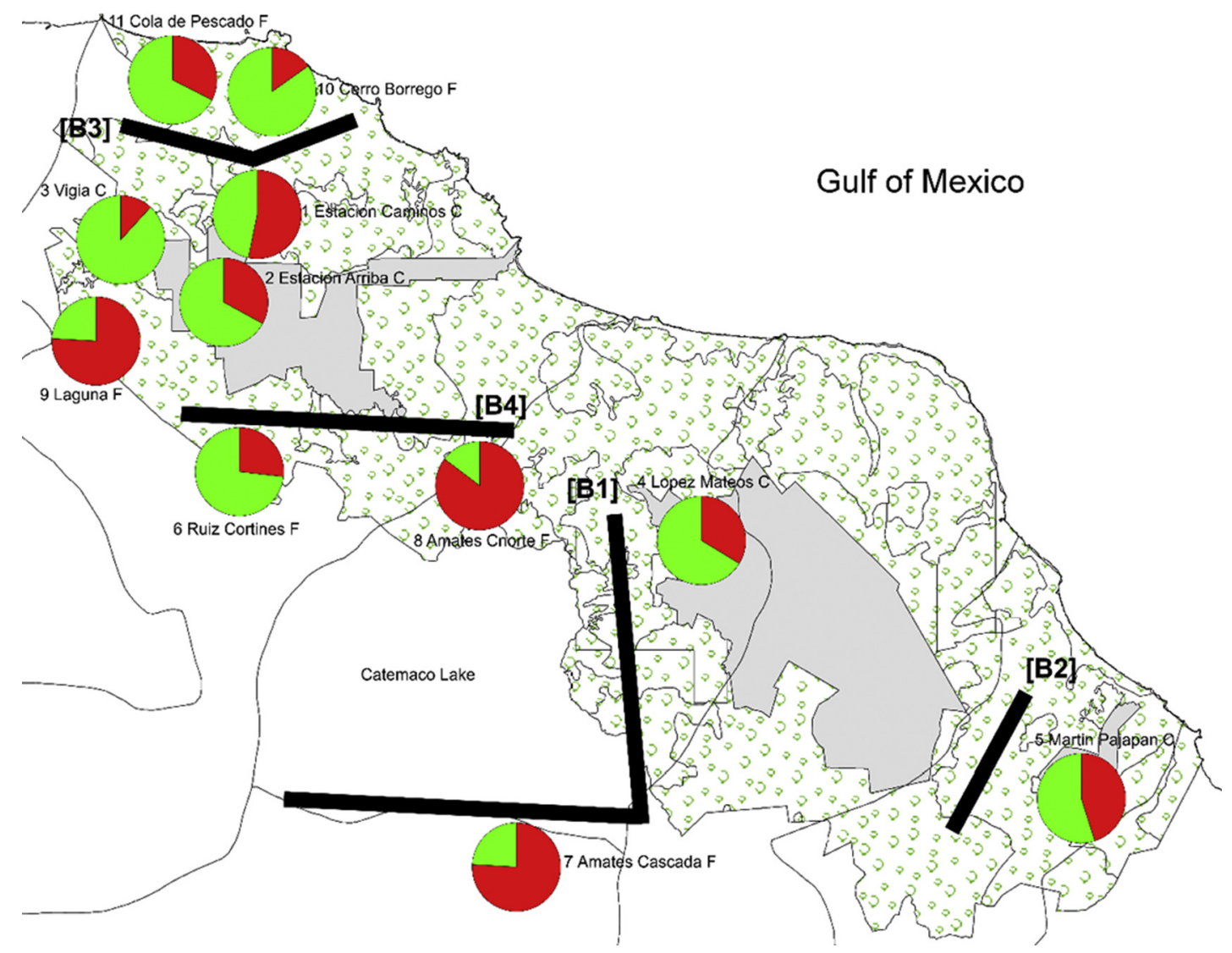

Figure 3. Map shows sampling localities representing 11 populations of $C$. alternans in Los Tuxtlas, Veracruz, Mexico. Each pie chart represents the proportions in each population of the 2 genetic groups as assigned by the program STRUCTURE. Green and red represent the genetic groups corresponding to conserved and fragmented sites, respectively. Numbers next to each symbol correspond to the population numbers given in Table 1. Black lines represent 4 detected barriers. 
in given years, the number of genetic donors per generation could be decreased. Local spatial distribution of sexes can lower reproductive success, decrease observed heterozygosity, and in some cases increase local differentiation (Cibrián-Jaramillo et al., 2009; Otero-Arnaiz \& Oyama, 2001). In this sense, we observed signals of recent bottlenecks (excess of heterozygosity) in both genetic groups of $C$. alternans with the models IAM, TPM and SMM were-significant $(p<0.010)$ with the loci CPX-2, APX-2 and GOT-2. Demographic bottlenecks also have been observed in other Chamaedorea palms (e.g. C. eliator, C. tepejilote, C. ernesti-augusti (Cibrián-Jaramillo et al., 2009; Luna et al., 2007). Commonly, Chamaedorea species occurred in aggregated clusters of individuals and occur at densities of less than 100 individuals per hectare in some areas at the scale of a few hundred individuals per hectare for most of its distribution (Penn et al., 2008; Pérez-Farrera et al., 2007). Low density of $C$. alternans within subpopulations could further limit pollen movement by reducing the number of donors, and increasing susceptibility to genetic drift by reducing local effective population sizes (Cibrián-Jaramillo et al., 2009; Flores \& Ashton, 2000). Despite the huge reduction in abundance because of drastic environment change, habitat destruction and illegal harvesting in the Los Tuxtlas region (Dirzo \& García, 1992; Pérez-Portilla \& Geissert-Kientz, 2004). Still fragmented and continuous populations of $C$. alternans show moderate to high values of population size such as the first group showing the highest values $\left(N_{e}=164\right.$ individuals) and the second genetic group $\left(N_{e}=154\right)$. Studies in conservation genetics have pointed out a rule to define the effective population size to avoid genetic harmful effects (Frankham, Ballou, \& Briscoe, 2002; Pickup \& Barrett, 2013). A population with an effective size of 50 is considered the minimum to maintain sufficient genetic variability, while 500 individuals are required to offset effective drift (Charlesworth, 2009; Vicoso \& Charlesworth, 2009). One possible explanation is that the genetic bottleneck following deforestation was not severe enough to lower the effective size of remnant populations to a point where loss of genetic diversity would be pronounced (Browne et al., 2015; Kramer, Ison, Ashley, \& Howe, 2008; Lowe et al., 2005). This could lead to high standing genetic diversity in the populations left after fragmentation, providing a buffer against genetic erosion (Hamrick, 2004; Young \& Clarke, 2000).

Genetic differentiation $F_{S T}$ parameters are more variable within groups of populations than among groups (Table 2) and resulted slightly higher when we compared between genetic groups obtained with the Bayesian-clustering approach (i.e. cluster 1 , green and cluster 2 red). This could be because both genetic groups have a slightly moderate genetic differentiation between each other, perhaps due to geographic isolation in the fragments or may also indicate an incipient effect produced by the selective extraction of individuals of $C$. alternans. For instance, the genetic/geographic barriers (e.g. B1) observed in populations of $C$. alternans (Fig. 3) separated the east part of Catemaco Lake from southern portion of Catemaco Lake, which represents a barrier to the movement of pollinators and dispersers (Dirzo \& García, 1992; Dirzo et al., 1997). The second barrier (e.g. B2) divides San Martín Pajapan volcano mountain chain reaching $1,900 \mathrm{~m}$ of elevation, that probably acting as a barrier against gene flow between populations (Guevara et al., 2005). The third and fourth barriers (e.g. B3 and B4) that divide populations from Cola de Pescado and Cerro Borrego occur in several isolated remnants of vegetation, which play an essential role acting as a vegetation corridor that linked populations in the last northern remnants of tropical rain forest in the state of Veracruz. Particularly, for $C$. alternans these results indicate the importance of fragmented areas for the maintenance of connectivity in modified landscapes, current distribution of fragmented remnants in the habitats may not completely isolate palm populations. Studies suggested that, if established on degraded sites along the forest edge, theses buffer zones can act as catalysist for recolonization by the native flora through the influence on microclimate, soil fertility, suppression of dominant grasses and habitat for seed-dispersing wildlife (Kramer et al., 2008; Lowe et al., 2005; Schroth et al., 2011). Seed dispersal from conserved to fragmented areas may be responsible for the low-moderate genetic differentiation and in the long term can balance fragmentation if population size is not too small (Barfod et al., 2011; Hamrick, 2010; Montoya, Zavala, Rodríguez, \& Purves, 2008; Young \& Clarke, 2000).

More important, it is essential to consider the role of natural selection influencing the genetic structure of the studied populations. For instance, the contrasting environmental conditions due to changes in the conserved and fragmented populations may impose a selection pressure. Recently, Pérez-Portilla and Geissert-Kientz (2004) performed the potential distribution of $C$. elegans, a close relative to $C$. alternans. The results show the variables that help explain the distribution of this species are related to climate (temperature and precipitation), edaphic (drainage surface) and physiographic (landform). In relation to climate, it could have a strong influence on the populations because altered landscapes can be very heterogeneous (Eiserhardt, Svenning, Kissling, \& Balslev, 2011; Svenning, 2001). Also, studies have emphasized that landforms have an indirect effect on the distribution of species, thus affecting moisture availability, solar radiation and wind exposure (Ohmann \& Spies, 1998; Souza \& Martins, 2003; Wagner et al., 2014). Hodel (1992) also mentioned that the presence of salinity in the soil does not favour the development and growth of Chamaedorea. In this sense, $C$. alternans have been subject to a very complex pattern of selective pressure that resulted detectable with the analysis of deviation of neutrality in the loci surveyed in C. alternans (i.e. performed with FDIST2 and LOSITAN programs). We found 3 outlier significant loci the GOT-2, EST-1 and APX-1 appearing with lower $F_{S T}$ distribution that possibly suggested balancing selection shown in populations from conserved and fragmented. Balancing selection refers to forms of natural selection which work to maintain genetic polymorphisms or multiple alleles within a population (Charlesworth, 2006; Wright \& Gaut, 2005). Although, the landscape of $C$. alternans is highly fragmented, we observed a continuous natural gene flow among more geographically close populations than between those in distant stands; these genetic aggregating structure was previously reported by Otero-Arnaiz and Oyama (2001) having important implications for management because 
it would increase the variability of the populations (Guevara et al., 2005). One possible explanation is where several populations may comprise a much bigger and more isolated area than the large ones contains, probably a high rate of dispersal from fragmented populations leads to the possibility to maintain the same or more genetic diversity than conserved habitat. More important, the interaction among migration and population size are the mechanism that regulates the preservation of genetic diversity in isolated environments (Andre et al., 2008; Willi et al., 2006; Zhang et al., 2012). Directional selection was observed in the outlier loci, the GOT-1 did show higher $F_{S T}$ values in populations from fragmented habitats, that probably indicated directional selection a decrease of genetic diversity, called selective sweep (Maynard-Smith \& Haigh, 1974) and an excess of high-frequency mutations (Fay \& Wu, 2000). Decrease and maintenance of genetic variability and increased population differentiation, signify that populations of $C$. alternans, have been subject to a historical differential selective pressure at the ecological and the landscape level, both effects could lead to disturb pollination, dispersion processes (Andre et al., 2008) reduce the distribution areas, modifying to the long term the effective population size (Broadhurst \& Young, 2007; Lowe et al., 2005; Vicoso \& Charlesworth, 2009). The results are in agreement with the study of Pérez-Portilla and Geissert-Kientz (2004) that indicated that Chamaedorea species are susceptible to cool temperatures, precipitation regimes, prolonged dry season and soil with poor drainage, which also have been identified as important variables in the ecological and physiological processes to the species belonging to Chamaedorea (Eiserhardt et al., 2011; Hodel, 1992; Svenning, 2001). In small populations we can expect negative impacts on population genetic parameters, such as an increase of inbreeding, and a reduction of genetic variation caused by genetic drift, founder effect or accumulation of deleterious mutations (Andre et al., 2008; Farwig et al., 2008; Moreira et al., 2009; Young \& Pickup, 2010). In Mexico, which like other countries currently is undergoing increased anthropogenic pressures, conservation efforts seem to be necessary that could diminish the effects of fragmentation on tropical tree species populations. One possible way to help to mitigate the effects of fragmentation is to create continuous corridors between fragments. Stepping stone fragments allow the mixing of populations and the sharing of genes, thereby reducing problems of inbreeding depression and genetic stochasticity in fragmented populations (Kramer et al., 2008; Oostermeijer et al., 2003; Schroth et al., 2011). Also, a possible conservation strategy could be to legalize the commercial trade of leaves with a horticultural company established in the Los Tuxtlas region which provides leaves for the national and international markets to fulfil ornamental demand (Ash, Gorchov, \& Endress, 2013; Bridgewater et al., 2006; Flores \& Ashton, 2000; Newton \& Freyfogle, 2005).

\section{Acknowledgments}

To D. Lugo-Aquino, O. Chassin-Noria, S. Zárate Pedroche and V. Rocha-Ramírez, for technical assistance and suggested improvements to the manuscript.

\section{References}

Aguilar, R. M., Quesada, L., Ashworth, Y., Herrerias, D., \& Lobo, J. A. (2008). Genetic consequences of habitat fragmentation in plant populations: susceptible signals in plant traits and methodological approaches. Molecular Ecology, 17, 5177-5188.

Andre, T., Lemes, M. R., Grogan, J., \& Gribel, R. (2008). Post-logging loss of genetic diversity in a mahogany (Swietenia macrophylla King Meliaceae) population in Brazilian Amazonia. Forest Ecology and Management, 255, 340-345.

Ash, J. D., Gorchov, D. L., \& Endress, B. A. (2013). Rapid assessment of sustainable harvesting of leaves from the understory palm, Chamaedorea radicalis. The Southwestern Naturalist, 58, 70-80.

Bacon, C. D., \& Bailey, C. D. (2006). Taxonomy and conservation: a case study from Chamaedorea alternans. Annals of Botany, 98, 755-763.

Barrera-Bassols, N. (1992). Impacto ecológico y socioeconómico de la ganadería bovina en Veracruz. In E. Boege, \& H. Rodríguez (Eds.), Desarrollo y medio ambiente en Veracruz (pp. 79-115). Ciudad de México: CIESAS-Golfo, Instituto de Ecología, A.C.

Barfod, A. S., Hagen, M., \& Borchsenius, F. (2011). Twenty-five years of progress in understanding pollination mechanisms in palms (Arecaceae). Annals of Botany, 108, 1503-1516.

Belkhir, K., Borsa, P., Chikhi, L., Raufaste, N., \& Bonhomme, F. (1996-2004). GENETIX 4.05, logiciel sous Windows TM pour la genetique des populations. Montpellier: Laboratoire Genome, Populations, Interactions, CNRS UMR 5171, Universitede Montpellier II.

Beaumont, M. A. (2005). Adaptation and speciation: What can Fst tell us? Trends in Ecology and Evolution, 20, 435-440.

Beaumont, M. A., \& Balding, D. J. (2004). Identifying adaptive genetic divergence among populations from genome scans. Molecular Ecology, 13, 969-980.

Beerli, P., \& Felsenstein, J. (2001). Maximum likelihood estimation of a migration matrix and effective population sizes in $\mathrm{n}$ subpopulations by using a coalescent approach. Proceedings of the National Academy of Sciences of the United States of America, 98, 4563-4568.

Bridgewater, S. G. M., Pickles, P., Garwood, N. C., Penn, M., Bateman, R. M., Morgan, H. P., et al. (2006). Chamaedorea (Xate) in the greater Maya mountains in the Chiquibul forest reserve, Belize: an economic assessment of a non-timber forest product. Economic Botany, 60, 265-283.

Broadhurst, L., \& Young, A. (2007). Seeing the wood and the trees-predicting the future for fragmented plant populations in Australian landscapes. Australian Journal of Botany, 55, 250-260.

Browne, L., Ottewell, K., \& Karubian, J. (2015). Short-term genetic consequences of habitat loss and fragmentation for the neotropical palm Oenocarpus bataua. Heredity, 115, 389-395.

Charlesworth, D. (2006). Balancing selection and its effects on sequences in nearby genome regions. PLoS Genetics, 2, e64.

Charlesworth, B. (2009). Effective population size and patterns of molecular evolution and variation. Nature, 10, 195-205.

Cibrián-Jaramillo, A., Bacon, C. D., Garwood, N. C., Bateman, R. M., Thomas, M. M., Russell, S., et al. (2009). Population genetics of the understory fishtail palm Chamaedorea ernesti-augusti in Belize: high genetic connectivity with local differentiation. BMC Genetics, 10, 65.

Conkle, M. T., Hodgkiss, P. D., Nunnally, L. B., \& Hunter, S. C. (1982). Starch gel electrophoresis of pine seed: a laboratory manual. Berkeley: U.S.: Forest Service General Technical Report PSW-64.

Cornuet, J. M., \& Luikart, G. (1996). Description and power analysis of two tests for detecting recent population bottlenecks from allele frequency data. Genetics, 144, 2001-2014.

Cheliak, W. M., \& Pitel, J. A. (1984). Techniques for starch gel electrophoresis of enzymes from forest tree species. Canadian Forestry Service Information Report PI-X-42. Petawawa, Ontario: Petawawa National Forestry Institute.

Dirzo, R., \& García, M. (1992). Rates of deforestation in Los Tuxtlas, a neotropical area in southeast Mexico. Conservation Biology, 6, 84-90.

Dirzo, R., González-Soriano, E., \& Vogt, R. (1997). La región de Los Tuxtlas. In E. González-Soriano, R. Dirzo, \& R. C. Vogt (Eds.), Historia Natural de Los Tuxtlas (pp.3-6). Ciudada de México: UNAM. 
Dieringer, D., \& Schlötterer, C. (2003). Microsatellite analyser (MSA): A platform independent analysis tool for large microsatellite data sets. Molecular Ecology Notes, 3, 167-169.

Earl, D. A., \& Von Holdt, B. M. (2011). STRUCTURE HARVESTER: A website and program for visualizing STRUCTURE output and implementing the Evanno method. Conservation Genetics Resources, 4, 359-361.

Eiserhardt, W. L., Svenning, J. C., Kissling, W. D., \& Balslev, H. (2011). Geographical ecology of the palms (Arecaceae): determinants of diversity and distributions across spatial scales. Annals of Botany, 108, 1391-1416.

Excoffier, L., \& Lischer, H. E. L. (2010). Arlequin suite ver 3.5: a new series of programs to perform population genetics analyses under Linux and Windows. Molecular Ecology Resources, 10, 564-567.

Evanno, G., Regnaut, S., \& Goudet, S. (2005). Detecting the number of clusters of individuals using the software STRUCTURE: a simulation study. Molecular Ecology, 14, 2611-2620.

Falush, D., Stephens, M., \& Pritchard, J. K. (2003). Inference of population structure using multilocus genotype data: linked loci and correlated allele frequencies. Genetics, 164, 1567-1587.

Farwig, N., Braun, C., \& Bohning-Gaese, K. (2008). Human disturbance reduces genetic diversity of an endangered tropical tree, Prunus africana (Rosaceae). Conservation Genetics, 9, 317-326.

Fay, J. C., \& Wu, C. I. (2000). Hitchhiking under positive Darwinian selection. Genetics, 155, 1405-1413.

Figueroa-Esquivel, E. M., Puebla-Olivares, F., Eguiarte, L. E., \& Núñez-Farfán, J. (2010). Genetic structure of a bird-dispersed tropical tree (Dendropanax arboreus) in a fragmented landscape in Mexico. Revista Mexicana de Biodiversidad, 81, 789-800.

Flores, C. S., \& Ashton, P. M. S. (2000). Harvesting impact and economic value of Geonoma deversa, Arecaceae, an understory palm used for roof thatching in the Peruvian Amazon. Economic Botany, 54, 267-277.

Frankham, R., Ballou, J. D., \& Briscoe, D. A. (2002). Introduction to conservation genetics. Cambridge (UK): Cambridge University Press.

Goldstein, D. B., Ruiz-Linares, A., Cavalli-Sforza, L. L., \& Feldman, M. W. (1995). An evaluation of genetic distances for use with microsatellite loci. Genetics, 139, 463-471.

Govaerts, R., \& Dransfield, J. (2005). World checklist of Arecaceae. The Board of Trustees of the Royal Botanic Gardens, Kew. Retrieved on March 11, 2008, from: http://www.kew.org/wcsp/.

Guevara, S., Loborde, J., \& Sánchez-Ríos, G. (2005). Los Tuxtlas. El Paisaje de la Sierra. Xalapa: Instituto de Ecología, A.C. y Unión Europea.

Hamrick, J. (2004). Response of forest trees to global environmental changes. Forest Ecology and Management, 197, 323-335.

Hamrick, J. (2010). Pollen and seed movement in disturbed tropical landscapes. In J. A. DeWoody, J. W. Bickham, C. H. Michler, K. M. Nichols, O. E. Rhodes, \& K. E. Woeste (Eds.), Molecular approaches in natural resource conservation and management. New York: Cambridge University Press.

Hodel, D. R. (1992). Chamaedorea palms: the species and their cultivation. Lawrence, Kansas: Allen Press, The International Palm Society.

Hubisz, M., Falush, D., Stephens, M., \& Pritchard, J. (2009). Inferring weak population structure with the assistance of sample group information. Molecular Ecology Resources, 9, 1322-1332.

Kettle, C. J., Hollingsworth, P. M., Jafre, T., Moran, B., \& Ennos, R. A. (2007). Identifying the early genetic consequences of habitat degradation in a highly threatened tropical conifer, Araucaria nemorosa Laubenfels. Molecular Ecology, 16, 3581-3591.

Kramer, A. T., Ison, J. L., Ashley, M. V., \& Howe, H. F. (2008). The paradox of forest fragmentation genetics. Conservation Biology, 22, 878-885.

Lowe, A. D., Boshier, M. W., Bacles, C., \& Navarro, C. (2005). Genetic resource impacts of habitat loss and degradation; reconciling empirical evidence and predicted theory for neotropical trees. Heredity, 95, 255-273.

Luikart, G., \& Cornuet, J. M. (1998). Empirical evaluation of a test for identifying recently bottlenecked populations from allele frequency data. Conservation Biology, 12, 228-237.

Luna, R., Epperson, B. K., \& Oyama, K. (2005). Spatial genetic structure of two sympatric neotropical palms with contrasting life histories. Heredity, 95, 296-305.
Luna, R., Epperson, B. K., \& Oyama, K. (2007). High levels of genetic variability and inbreeding in two Neotropical dioecious palms with contrasting life histories Heredity, 99, 466-476.

Manni, F., Guerard, E., \& Heyer, E. (2004). Geographic patterns of (genetic, morphologic, linguistic) variation: how barriers can be detected by "Monmonier's algorithm". Human Biology, 76, 173-190.

Maynard-Smith, J., \& Haigh, J. (1974). The hitch-hiking effect of a favourable gene. Genetic Resources, 23, 23-35.

Miller, M. P. (1997). Tools for population genetics analyses (TFPGA) 1.3. A windows program for the analysis of allozymes and molecular population genetic data. Computer software distributed by author.

Montoya, D., Zavala, M. A., Rodriguez, M. A., \& Purves, D. W. (2008). Animal versus wind dispersal and the robustness of tree species to deforestation. Science, 320, 1502-1504.

Moreira, P. A., Fernandes, G. W., \& Collevatti, R. G. (2009). Fragmentation and spatial genetic structure in Tabebuia ochracea (Bignoniaceae) a seasonally dry Neotropical tree. Forest Ecology and Management, 258, 2690-2695.

Newton, J. L., \& Freyfogle, E. T. (2005). Sustainability: a dissent. Conservation Biology, 19, 23-32.

Ohmann, J. L., \& Spies, T. A. (1998). Regional gradient analysis and spatial pattern of woody plant communities of Oregon forest. Ecological Monographs, 2, 151-182.

Oostermeijer, J. G. B., Luijten, S. H., \& Den Nijs, J. C. M. (2003). Integrating demographic and genetic approaches in plant conservation. Biological Conservation, 113, 389-398.

Otero-Arnaiz, A., \& Oyama, K. (2001). Reproductive phenology, seed-set and pollination in Chamaedorea alternans, an under story dioecious palm in a rain forest in Mexico. Journal of Tropical Ecology, 17, 745-754.

Oyama, K. (1990). Variation in growth and reproduction in neotropical dioecidous palm Chamaedorea tepejilote. Journal of Ecology, 78, 648-653.

Penn, M., Moncrieff, C., Bridgewater, S., Garwood, N., Chan, I., \& Cho, P. (2008). Using GIS techniques to model the distribution of the economically important xaté palm Chamaedorea ernesti-augusti within the Greater Maya Mountains, Belize. Systematics and Biodiversity, 7, 63-72.

Pérez-Farrera, M. A., Vovides, A. P., Martínez-Camilo, R., \& MeléndezMartínez, N. (2007). New endangered Chamaedorea (Arecaceae) reports from southeastern Mexico with notes on conservation status, habitat and distribution. Rhodora, 109, 187-196.

Pérez-Portilla, E., \& Geissert-Kientz, D. (2004). Distribucion potencial de la palma camedor (Chamaedorea elegans Mart.) en el estado de Veracruz, México. Revista Chapingo, Serie Horticultura, 10, 247-252.

Porter-Morgan, H. (2007). Trips as primary pollinators of sympatric species of Chamaedorea (Arecaceae) in Belize. New York City: The City University of New York.

Pickup, M., \& Barrett, S. C. H. (2013). The influence of demography and local mating environment on sex ratios in a wind-pollinated dioecious plant. Ecology and Evolution, 3, 629-639.

Piry, S., Luikart, G., \& Cornuet, J. M. (1999). BOTTLENECK: a computer program for detecting recent reductions in the effective population size using allele frequency data. Journal of Heredity, 90, 502-503.

Pitel, J. A., \& Cheliak, W. M. (1984). Effect of extraction buffers on characterization of isoenzymes from vegetative tissues of five conifers species: a user's manual. In Information Report PI-X-34, Petawawa National Forestry Institute. Chalk River, Ontario: Canadian Forestry Service.

Pritchard, J., Stephens, M., \& Donnelly, P. (2000). Inference of population structure using multilocus genotype data. Genetics, 155, 945-959.

Rios, L. D., Fuchs, E. J., Hodel, D. R., \& Cascante-Marın, A. (2013). Neither insects nor wind: ambophily in dioecious Chamaedorea palms (Arecaceae). Plant Biology, 16, 702-710.

Schroth, G., Faria, D., Araujo, M., Bede, L., Van Bael, S. A., Cassano, C. R., et al. (2011). Conservation in tropical landscape mosaics: the case of the cacao landscape of southern Bahia, Brazil. Biodiversity and Conservation, 20, 1635-1654.

Semarnat-RBLT (Secretaría de Medio Ambiente y Recursos Naturales-Reserva de la Biosfera Los Tuxtlas). 2001. Programa de Manejo de la Reserva de la Biosfera Los Tuxtlas (Borrador). Ciudad de México: Semarnat. 
Sherburne, G. J., \& Lewis, S. D. (1970). Polymorphism in the esterases of Atlantic herring. Transactions of the American Fisheries Society, 99, $147-151$.

Slatkin, M. (1995). A measure of population subdivision based on microsatellite allele frequencies. Genetics, 139, 457-462.

Souza, A. F., \& Martins, F. R. (2003). Spatial distribution of an undergrowth palm in fragments of the Brazilian Atlantic Forest. Plant Ecology, 164, 141-155.

Svenning, J. C. (2001). On the role of microenvironmental heterogeneity in the ecology and diversification of neotropical rain-forest palms (Arecaceae). The Botanical Review, 67, 1-53.

Stuber, C. W., Wendel, J. M., \& Goodman, M. M. (1988). Techniques and scoring procedures for starch gel electrophoresis of enzymes from maize (Zea mays). In Technical Bulletin 286. North Carolina: North Carolina State University.

Trejo, I., \& Dirzo, R. (2000). Deforestation of seasonally dry tropical forest: a national and local analysis in Mexico. Biological Conservation, 94, 133-142.

Vicoso, B., \& Charlesworth, B. (2009). Effective population size and the faster-X effect: an extended model. Evolution, 63, 2413-2426.

Wagner, F., Rossi, V., Aubry-Kientz, M., Bonal, D., Dalitz, H., Gliniars, R., et al. (2014). Pan-tropical analysis of climate effects on seasonal tree growth. PLoS One, 9, e92337.

Waples, R. S. (2006). A bias correction for estimates of effective population size based on linkage disequilibrium at unlinked gene loci. Conservation Genetics, 7, 167-184.

Waples, R. S., \& Do, C. (2008). LdNe: a program for estimating effective population size from data on linkage disequilibrium. Molecular Ecology Resources, $8,753-756$.
Weir, B. S., \& Cockerham, C. C. (1984). Estimating F-statistics for the analysis of population structure. Evolution, 38, 1358-1370.

Wendel, J. F., \& Weeden, N. F. (1989). Visualization and interpretation of plant isozymes. In D. E. Soltis, \& P. S. Soltis (Eds.), Isozymes in plant biology. London: Chapman and Hall.

Willi, Y., Van Buskirk, J., \& Hoffmann, A. A. (2006). Limits to the adaptive potential of small populations. Annual Review of Ecology, Evolution, and Systematics, 37, 433-458.

Wright, S. I., \& Gaut, B. S. (2005). Molecular population genetics and the search for adaptive evolution in plants. Molecular Biology and Evolution, 22, 506-519.

Yeh, F. C. H., \& O’Malley, D. (1980). Enzyme variations in natural populations of Douglas-fir, Pseudotsuga menziesii (Mirb.) Franco, from British Columbia. 1. Genetic variation patterns in coastal populations. Silvae Genetica, 29, 83-92.

Young, A., \& Clarke, G. (2000). Genetics, demography and viability of fragmented populations. Series: Conservation Biology 4 Cambridge: University Press.

Young, A. G., \& Pickup, M. (2010). Low S allele numbers limit mate availability, reduce seed set and skew fitness in small populations of a self-incompatible plant. Journal of Applied Ecology, 47, 541-548.

Zhang, X., Miao-Miao, S., Dong-Wei, S., \& Xiao-Yong, C. (2012). Habitat loss other than fragmentation per se decreased nuclear and chloroplast genetic diversity in a monoecious tree. PLoS ONE, 7, e39146. 